\title{
HOW IS LANGUAGE LEARNING AND APPRECIATION OF INDONESIAN LITERATURE USING CREATIVE AND INNOVATIVE MODELS? \\ Nia Oktaviani \\ niaoktaviani525@gmail.com
}

In the world of education teachers must create creative and innovative learning models, so that students are enthusiastic in the learning process. Creative and innovative learning will produce a generation that is intelligent, insightful and has high knowledge. At this time a variety of models and innovations are used by teachers in learning Indonesian. In learning Indonesian as a teacher facing problems and learning processes, especially in the cognitive aspects, namely the lack of understanding of teachers in teaching (Sukma, 2019). One of the subjects that is currently receiving much attention is Indonesian. Indonesian subjects who are serious about succeeding in becoming the national exam so that schools give more priority to Indonesian subjects. For this reason, teachers must use attractive learning models in learning Indonesian. In addition, the use of various learning models can increase students' understanding in learning, (Sukma, 2018).

According to Sukma (2016) Literary learning is an interesting learning. In literary works there are values of life, both spatial values, moral, social and so on. Literary learning is intended to improve the ability of students to enjoy, appreciate, and understand the work of sestra and take lessons from the sublime values that are hidden in it. According to Silfia, et al (2018) literary work is a form and result of works of art whose objects are humans and their lives using language as their medium. Literary work in the form of creativity in a beautiful language contains a series of inner experiences and imaginations derived from the appreciation of the author's social reality. In line with the opinion of Fitri, et al (2012), in essence literary works are a reflection of the reality of human life. Therefore, literary works always increase the attention of readers. Reading a variety of literary works will make us dissolve into the plot of the literary work. By type, literary works are divided into poems, prose, and drama. Each type has its own peculiarities.

According to Piliang, et al (2014) the ability to appreciate literary works is something that is very necessary both for the life of literature itself and for the appreciators. The ability to appreciate literature and think creatively is important in efforts to improve drama playing skills. 
Students who have good literary appreciation and creative thinking skills also have good play skills. According to Amin, et al (2013) the presence of oral literature in social life is a reflection of solidarity and identity recognition that is conveyed orally and has a specific purpose. With oral literature, ancient societies or ancestors of humanity expressed the turmoil of the soul and its reflections about life. The wealth of archipelago literary treasures can be broadly divided into three, namely oral literature, written literature and modern literature. According to Ramadan (2008) the use of language in learning and appreciation of Indonesian literature cannot be separated from the function of language and other components of interaction. The successful use of language as a means of interaction with the function is influenced by speech behavior factors and the context that underlies it. Therefore, the use of language can be seen as a system which involves the linguistic component, speech actors, and the context. Therefore, language learning and appreciation of Indonesian literature must be considered in the act of using language when interacting.

According to Tatalia, et al (2015) creative, interesting learning models can also help students in practice, such as writing, and can train students in developing creative and innovative ideas and ideas, one of which is to use STAD type cooperative learning models assisted with mind mapping, this has been applied by researchers, and the results of their research have increased the ability to understand and write students. In addition, creative models can develop student abilities in various aspects of language skills, such as reading, writing, listening, listening, presenting, and watching. According to Fitri, et al (2016) the learning model used by teachers should be a model that can improve critical thinking skills, and be innovative, so that learning is useful for themselves and their environment. In learning Indonesian language teachers can also use scientific learning models, and are applied in learning implementation activities by paying attention to the syntax of the model. In a scientific model with various innovations, such as a scientific model that is innovated with the media in learning. From scientific syntax, students initially observe, shows in the form of videos, then students ask questions about what they do not understand, and information they can gather then students make sense of the information the last time the teacher can display the second video or the teacher's work along with the format, then students are told to fill out and finally, communicate in front of the class. 


\section{Daftar Rujukan}

Amin, I., Ramadhan, S., \& Ermanto. (2013). Cerita rakyat penamaan desa di Kerinci: kategori dan fungsi sosial teks. Jurnal Bahasa, Sastra, dan Pembelajaran. 1(1) 31-41.

Fitri, N. S. et al. (2012). Resepsi sastra naskah drama Kau Tunggu Siapa Nilo karya Wisran Hadi. Jurnal Pendidikan Bahasa dan Sastra Indonesia. 1(1) 44-51.

Fitri,Y., Rahmadan,S., \& Tamsin, S., C. (2016). Pengaruh model pembelajaran kooperatif tipe think talkwrite berbantuan media gambar terhadap keterampilan menulis karangan argumentasi siswa kelas X SMA Negeri 5 Padang. Jurnal Pendidikan Bahasa dan Sastra Indonesia.5(2) 548-554.

Piliang, W. S. H., Atmazaki, \& Ramadhan, S. (2014). Konstribusi kemampuan apresiasi sastra dan berpikir kreatif terhadap keterampilan bermain drama pada siswa kelas XII IPS SMA Negeri 2 Rengat Kabupaten Indragiri Hul. Jurnal Bahasa, Sastra, dan Pembelajaran. 2(2) 75-87.

Ramadhan, R. (2008). Representasi kesatuan tindak tutur berbahasa Indonesia dalam pembelajaran di kelas (kajian etnografi komnikasi). Jurnal Diksi. 15(2) 120-136.

Silfia, M., Rahmadhan, S., \& Afnita. (2018). Permasalahan sosial dalam novel Di Batas Pelangi karya Achi Tm. Jurnal Diksi. 26(1) 11-17.

Sukma, E. (2016). Pembelajaran sastra yang integratif berbasis kompetensi. Proceeding of International Seminar on Languages and Arts: (ISLA). Atlantis press.

Sukma, E. (2018). Problem in language teaching in elementary school. international conference on languages and arts(ICLA 2018). Atlantis press.

Sukma, E. (2019). Problem in oral language teaching in primary school. Seventh international conference on languages and arts(ICLA 2018). Atlantis press.

Tatalia, R. G., Ramadhan, S., \& Ermanto. (2015). Pengaruh model pembelajaran kooperatif tipe STAD berbantuan pemetaan pikiran(MIND MAPPING) dengan mempertimbangkan motivasi belajar terhadap kemampuan menulis. Jurnal Bahasa Sastra dan Pembelajaran. 3(1) $36-45$. 